\title{
The Relationship Between the Nature of the Cell Wall and the Gram Stain.
}

\author{
By M. R. J. SALTON* \\ Department of Bacteriology, University of Manchester
}

(Received 1 May 1962)

\begin{abstract}
SUMMARY
None of the classes of major chemical constituents of the walls of bacteria and yeasts is exclusive to organisms which give a Gram-positive reaction. Walls of Gram-positive bacteria are richer in mucopeptide than are those of Gram-negative bacteria. The latter are characterized by high lipid contents. Yeast walls are rich in polysaccharide complexes. There appears to be a broad correlation between the Gram reaction and the decreased leakage of ${ }^{32} \mathrm{P}$ compounds from labelled cells on exposure to increasing ethanol concentrations in the range 50-100\% $(\mathrm{v} / \mathrm{v})$ ethanol. The data on the release of ${ }^{32} \mathrm{P}$ compounds are in accord with the cell-wall 'permeability' mechanism for the Gram reaction and imply quantitative rather than all or none differences in Gram behaviour. Mechanical rupture of the cell wall or digestion of the wall with lysozyme rendered organisms which had been previously Gram stained in suspension by the technique of Wensinck \& Boevé (1957), susceptible to decolorization with $96 \%(v / v)$ ethanol in water.
\end{abstract}

\section{INTRODUCTION}

Although the Gram reaction is probably the most widely used staining procedure in bacteriology, there has been no wholly acceptable explanation of the mechanism of its reaction despite the great proliferation of theories advanced since the description of the technique by Christian Gram in 1884. Many of the earlier views of the mechanism of the Gram reaction were discussed in some detail by Bartholomew \& Mittwer (1952). As pointed out by Salton (1961 $a$ ) it is now virtually impossible to propose any new theory to explain the Gram reaction, for the most likely possibilities have been covered at some time or other and all of the major classes of cellular constituents have been implicated. The theories propounded from the studies of the mechanism of the Gram reaction fall into two major groups: (i) those which involve the presence of a particular substance or class of substances which confer Gram positivity; (ii) those which invoke a difference in the 'permeability' of the cells to the dyes.

Much effort in the past has been concentrated on searching for specific bacterial substances which may account for the Gram-positive reaction. Thus a positive response to the Gram stain has been claimed to be due to lipoprotein (Stearn \& Stearn, 1924, 1930), lipids (Eisenberg, 1910; Schumacher, 1928), nucleoproteins and nucleic acids (Deussen, 1921; Dubos \& MacLeod, 1938; Henry, Stacey \& Teece, 1945; Henry \& Stacey, 1946; Webb, 1948); carbohydrate (Webb, 1948) and

* Present address : Department of Microbiology, University of New South Wales, Kensington, N.S.W., Australia. 
glycerophosphate substances (Schumacher, 1928; Mitchell \& Moyle, 1950, 1951, 1954). Fischer \& Larose (1952) suggested a similarity in chemical structure between highly degraded wool and the cytoplasmic membrane of Gram-positive bacteria. Other chemical constituents believed to be related to the Gram reaction in some unknown way include the polyamines found in greatest amounts in the Gramnegative group of bacteria (Herbst, Weaver \& Keister, 1958). Evidence that the Gram reaction was related to $\mathrm{Mg}$-ribonucleate in Gram-positive bacteria was presented by Henry et al. (1945) but an explanation of the stain reaction based on this proved less satisfactory when Mitchell \& Moyle (1954) made a thorough investigation of the ribonucleic acid (RNA) and deoxyribonucleic acid (DNA) contents of various bacteria. Further doubts that the Gram reaction was due to a Mg-ribonucleate + basic protein complex (Stacey, 1949) also came from the studies of Shugar \& Baranowska (1957), reinforcing the earlier conclusion of Lamanna \& Mallette (1950) that much of the nucleic acid can be extracted from yeast cells without loss of a Gram-positive reaction.

As an alternative to the mechanism of the Gram reaction based on a nucleic acid + basic protein complex as proposed by Stacey (1949), Mitchell \& Moyle (1950, $1951,1954)$ suggested a correlation between Gram positivity and the presence of phosphate esters ('XSP'). These phosphate esters were subsequently identified as mixed glycerol and ribitol phosphate polymers (Mitchell \& Moyle, 1958), substances now well known as the teichoic acids of bacterial walls (Armstrong, Baddiley, Buchanan, Carss \& Greenberg, 1958). The polyglycerophosphate of Staphylococcus aureus was given the name 'positic acid' by Mitchell \& Moyle (1958). However, Jones, Rizvi \& Stacey (1958) showed that most organisms (both Gram-positive and Gram-negative) contained 'XSP'. Thus it now seems unlikely that 'positic acid' could be directly responsible for Gram positivity.

The opponents of the idea that a specific cellular substance is responsible for the Gram reaction have sought other explanations, and 'permeability' factors have long been suggested as the basis of the differential staining observed. Thus, Burke \& Barnes (1929) concluded that the Gram reaction was due to differences in cell-wall permeability. Further support of the 'permeability' theories have come from the studies of Kaplan \& Kaplan (1933) and more recently from Bartholomew, Cromwell \& Finkelstein (1959). The studies of Wensinck \& Boevé (1957) on the pattern of extractibility with ethanol, of the crystal violet + iodine (CVI) complex from bacteria, provide convincing evidence that some 'permeability' effect is involved.

That the cell wall is involved in some manner seemed inescapable, especially from the loss of Gram positivity following mechanical crushing (Benians, 1920), lysozyme treatment of heated cells (Webb, 1948) or protoplast formation (Gerhardt, Vennes \& Britt, 1956). Although Chelton \& Jones (1959) have shown that disintegrated yeast cells can, under certain conditions, give a positive Gram reaction, it has been widely established that loss of Gram reaction occurs concomitantly with loss of cellular integrity (Bartholomew \& Mittwer, 1952). Since many of the theories of the mechanism of the Gram reaction were proposed before the more recent studies of the chemistry of bacterial cell walls, it seemed worth while to re-examine the problem in terms of present knowledge of the surface structure of bacteria. In this paper, details of the composition of bacterial cell walls from the present investiga- 
tion and from earlier studies (Salton, 1953a; Salton, 1958; Salton \& Pavlik, 1960) have been considered in relation to the Gram reaction and a possible method for studying the mechanism of the Gram differentiation is presented.

\section{METHODS}

Organisms and growth conditions. Unless otherwise specified, the following organisms used were laboratory strains: Alcaligenes faecalis (NCTC 8764); Bacillus brevis (NCTC 7577;) B. cereus P2;B. megaterium KM; Candida pulcherrima (NCYC 373); Chromobacterium prodigiosum; Clostridium perfringens (C. welchii); C. sporogenes; Corynebacterium hoffmanni; Corynebacterium xerosis; Escherichia coli $\mathbf{B}$; E. dispar (NCTC 4169); Klebsiella aerogenes (Aerobacter aerogenes) A 30; Lactobacillus arabinosus 17/5; Leuconostoc mesenteroides $\mathrm{P} 60$; Micrococcus lysodeikticus (NCTC 2665); Neisseria catarrhalis (kindly provided by Dr S. E. Hartsell); Proteus vulgaris; Pseudomonas fluorescens; Pseudomonas sp. (kindly provided by Dr J. M. Shewan); Saccharomyces cerevisiae (NCYC 366); Salmonella gallinarum; Spirillum serpens; Staphylococcus aureus Duncan; Streptococcus faecalis (NCTC 6782); Vibrio metchnikovii (NCTC 8443).

The organisms were grown on the following media: Clostridia on Robertson's cooked meat medium at $37^{\circ}$; Lactobacillus arabinosus and Leuconostoc mesenteroides on $2 \%$ Bacto Casitone + 0.1\% Marmite $+1 \%$ glucose $+2 \%$ agar at $30^{\circ} ;$ Spirillum serpens on $2 \%$ Bacto Casitone $+\mathbf{0} \cdot 1 \%$ Marmite $+1 \%$ glucose broth at $25^{\circ}-28^{\circ}$; yeasts on malt agar at $25^{\circ}$; all other organisms were cultivated on nutrient agar or nutrient broth at $30^{\circ}$ or $37^{\circ}$. The yeasts and Spirillum serpens were harvested after incubation for 2 days and all other organisms after $24 \mathrm{hr}$. Cultures of the sporeforming Bacillus species were harvested after incubation for 12-18 hr. The harvested organisms were generally washed three times with distilled water on the centrifuge. Organisms which showed any tendency to lyse under these conditions were harvested and washed in physiological saline.

For studying the leakage of ${ }^{32} \mathrm{P}$ compounds from organisms, these were grown under exactly the same conditions as specified above, except that the media were supplemented with ${ }^{32} \mathbf{P}$ as orthophosphate (Radiochemical Centre, Amersham, Buckinghamshire, England) in sterile saline solutions; $0.1 \mathrm{ml}$. sterile ${ }^{32} \mathrm{P}$ solution containing about $10^{7}$ counts $/ \mathrm{min}$. was added to $20 \mathrm{ml}$. portions of agar or liquid medium. The ${ }^{32} \mathrm{P}$-labelled organisms were harvested and washed as described above.

Gram reaction. Smears were stained by the method modified by Hucker (1921). All smears were blotted dry before decolorizing with $96 \%(\mathrm{v} / \mathrm{v})$ ethanol in water. The Gram method applied to bacterial suspensions by Wensinck \& Boevé (1957) was used as described by these authors with the modification of dissolving $\mathbf{0 . 9} \mathrm{g}$. Gurr's crystal violet in $100 \mathrm{ml} .0 .067 \mathrm{M}$-phosphate buffer ( $\mathrm{pH} 7$ ).

Leakage of ${ }^{32} \mathrm{P}$ compounds from micro-organisms. The effect of ethanol concentration on the leakage of ${ }^{32} \mathrm{P}$ compounds from labelled organisms was studied in the following way. Washed suspensions of organisms were pipetted into $1 \mathrm{~cm} . \times 7 \mathrm{~cm}$. test tubes and $1 \mathrm{ml}$. water or saline (when bacteria suspended in this fluid) added to each tube and the organisms packed by centrifugation. The volume of washed suspension added was adjusted so that each tube contained about 3-5 mg. dry weight organism. After centrifugation, the supernatant liquid was carefully sucked 
off with a pump so that the packed organisms were undisturbed, leaving a minimum of residual liquid in the tube (usually less than $0.05 \mathrm{ml}$.). Packed organisms were suspended in $1 \mathrm{ml}$. water or aqueous ethanol solution (concentrations of ethanol ranging from 25-100\%, v/v) and allowed to stand at room temperature (about $20^{\circ}$ ) for specified periods. Organisms were deposited by centrifugation for $10 \mathrm{~min}$. at room temperature and the supernatant liquids further clarified when necessary by centrifugation. The leakage of ${ }^{32} \mathrm{P}$ compounds was determined with a Geiger counter by measuring the radioactivity of $0.2 \mathrm{ml}$. samples of supernatant fluid dried on planchettes as described by Roberts, Abelson, Cowie, Bolton \& Britten (1955).

The time course of leakage in 96 and $100 \%(\mathrm{v} / \mathrm{v})$ ethanol was determined by preparing a series of test tubes containing ${ }^{32} \mathrm{P}$-labelled organisms as described above, adding the ethanol and filtering off the organisms on Oxoid bacteriological membrane filters. Filtration was rapid (10 sec. for about $1 \mathrm{ml}$. cell suspension) thus permitting samples to be taken at times much shorter than would have been possible by using centrifugation for removal of the extracted organisms. The ${ }^{32} \mathrm{P}$ contents of the filtrates were determined in the usual way.

Isolation and composition of cell walls. Cell walls were isolated as described by Salton \& Horne (1951). Analytical procedures used were those given in earlier studies (Salton, 1953a; Salton \& Pavlik, 1960). 'Total lipid' was determined by extraction with ether after preliminary hydrolysis with $6 \mathrm{~N}-\mathrm{HCl}$ for $2 \mathrm{hr}$. at $100^{\circ}$ (Salton, 1953a). Amino sugar contents were estimated by the Rondle \& Morgan (1955) method after previous hydrolysis of cell walls for $2 \mathrm{hr}$. with $2 \mathrm{~N}-\mathrm{HCl}$ at $100^{\circ}$.

\section{RESULTS}

Chemical composition of walls of Gram-positive and Gram-negative organisms

Extensive investigations of the chemistry of bacterial cell walls (Salton, 1961 b) and yeast walls (Falcone \& Nickerson, 1956; Kessler \& Nickerson, 1959; Northcote $\&$ Horne, 1952) have been made during the past 10 years; analyses have been

Table 1. Major classes of cell-roall constituents and the Gram reaction of certain micro-organisms

$\left.\begin{array}{l}\text { Gram-positive organisms } \\ \text { Yeasts } \\ \text { Saccharomyces cerevisiae } \\ \text { Candida } \text { spp. } \\ \text { Bacteria } \\ \text { Micrococcus lysodeilticus } \\ \text { Staphylococcus aureus } \\ \text { Streptococci } \\ \text { Corynebacterium } \\ \text { Gram-negative organisms } \\ \text { Escherichia coli } \\ \text { Aerobacter aerogenes } \\ \text { Pseudomonas spp. } \\ \text { Spirillum serpens }\end{array}\right\}$

Major chemical components of cell walls

Polysaccharide, protein, lipid

Polysaccharide, protein

Mucopeptide

Mucopeptide, teichoic acid

Mucopeptide, teichoic acid, polysaccharide

Mucopeptide, polysaccharide

Protein, polysaccharide, lipid, mucopeptide

performed on a large enough variety of Gram-positive and Gram-negative species to give a comprehensive picture of the major chemical constituents of walls from both groups. The principal types of chemical constituents found in walls of Gram- 
positive and Gram-negative organisms are summarized in Table 1. One of the most conspicuous differences between the walls of Gram-positive and Gram-negative bacteria observed in the earlier studies (Salton, 1953a) was the higher lipid contents of walls of the latter group. The amino sugar contents of the walls of Gram-positive bacteria were generally higher than those of Gram-negative organisms, such a difference probably being a reflexion of the total amount of mucopeptide (peptidopolysaccharide or glycopeptide) component in the wall. Thus, as suggested by Salton (1958) a 'spectrum' of lipid and amino sugar contents exists and quantitative results for the walls of a variety of Gram-negative bacteria are compared with the range observed for Gram-positive organisms (Salton \& Pavlik, 1960) in Table 2.

Table 2. Amino sugar and lipid contents of cell walls of Gram-negative and Gram-positive micro-organisms

\begin{tabular}{|c|c|c|}
\hline Gram-negative & $\begin{array}{c}\text { Amino } \\
\text { sugar } \\
(\%)\end{array}$ & $\begin{array}{c}\text { Total } \\
\text { lipid } \\
(\%)\end{array}$ \\
\hline Vibrio metchnikovii* & 1.8 & $11 \cdot 2$ \\
\hline Aerobacter aerogenes & $\mathbf{2}$ & $14 \cdot 6$ \\
\hline Chromobacterium prodigiosum & 2 & $12 \cdot 8$ \\
\hline Escherichia coli* & $\mathbf{3}$ & 20 \\
\hline Salmonella gallinarum & 3.5 & 22 \\
\hline Proteus morganii & $4 \cdot 1$ & 一 \\
\hline P. vulgaris & $5 \cdot 1$ & $17 \cdot 6$ \\
\hline Escherichia dispar & $5 \cdot 0$ & $12 \cdot 6$ \\
\hline Spirillum serpens* & $6 \cdot 8$ & 一 \\
\hline Alcaligenes faecalis & $7 \cdot 6$ & 一 \\
\hline Neisseria catarrhalis & $8 \cdot 1$ & $12 \cdot 2$ \\
\hline Bacillus brevis & 14.5 & $\mathbf{2 \cdot 7}$ \\
\hline \multicolumn{3}{|l|}{ Gram-positive } \\
\hline Candida pulcherrima & $1 \cdot 2$ & $5 \cdot 4$ \\
\hline Saccharomyces cerevisiae* & 1-2 & $8 \cdot 5-10$ \\
\hline Staphylococcus aureus & 17 & 一 \\
\hline Bacillus megaterium & 18 & $\mathbf{0}$ \\
\hline Micrococcus lysodeikticus* & $16-22$ & $\mathbf{0}$ \\
\hline Bacillus cereus* & 31-32 & $\mathbf{0}$ \\
\hline
\end{tabular}

* Data from earlier studies: Northcote \& Horne (1952); Salton $(1953 a, 1958)$; Salton \& Pavlik (1960); Salton \& Shafa (1958).

In considering the chemical nature of the cell wall in relation to the Gram reaction (Table 1), it became apparent that Gram positivity could not be correlated with the presence of one particular type of substance in the cell wall. Thus, the teichoic acids (Armstrong et al. 1958) are present in only certain Gram-positive bacteria, and similarly, polysaccharide components are found in some and not in others (Salton, $1961 b$ ). All of the Gram-positive bacteria contain mucopeptides (glycopeptides) and all of the yeast walls are rich in polysaccharides and polysaccharide complexes (Northcote \& Horne, 1952; Kessler \& Nickerson, 1959). Although the walls of Gram-negative bacteria were rich in lipids, the lipid content of yeast walls may be as high as $10 \%$ and as low as $1 \%$ (Kessler \& Nickerson, 1959). These considerations of the chemistry of cell walls led to the conclusion that the Gram reaction is not due to the presence of any specific substance in the wall and that several types of polymeric substances may serve equally well as wall structures for Gram-positive organisms. 


\section{Influence of ethanol concentration on the leakage of ${ }^{32} \mathrm{P}$ compounds across the walls of Gram-positive and Gram-negative bacteria}

In their analysis of the Gram reaction Wensinck \& Boevé (1957) showed that the amounts of crystal violet and iodine taken up was similar for Gram-positive and Gram-negative organisms. The main divergence in behaviour was found in the extractability of the CVI complex from the stained organisms washed in aqueous ethanol solutions ranging from about 90-100\%, $/ \mathrm{v}$. Thus under these conditions the CVI in Gram-positive organisms remained largely unextractable despite the fact that the CVI complex formed by mixing solutions of the Gram reagents was completely solubilized in such concentrations of aqueous ethanol. If the CVI is not rendered alcohol-insoluble by being bound to specific chemical constituents present in only Gram-positive organisms then other explanations of the results of Wensinck \& Boevé (1957) would have to be sought. As an alternative to the possession of a specific 'Gram-positive' chemical entity it seemed conceivable that the Gram differentiation brought about by decolorizing with $96 \%$ ethanol may result from a dehydration of the wall structures and consequent decrease in pore size, thus impeding the passage of small molecules across the wall and rendering the CVI complex inaccessible to extraction. Any information on the passage of small molecules across the walls (release from inside as well as passage from the external medium into the cell) when organisms are suspended in ethanol concentrations used in Gram differentiation may lead to a greater understanding of the mechanism of the Gram reaction.

To test the possibility that the passage of small molecules across the outer envelope is impeded when Gram-positive organisms are exposed to ethanol concentrations which bring about the Gram differentiation, the release of ${ }^{32} \mathbf{P}$ compounds from organisms suspended in aqueous ethanol solutions $(25-100 \%, v / v)$ was investigated. The influence of ethanol concentration on the leakage of ${ }^{32} \mathrm{P}$ compounds from a variety of Gram-positive and Gram-negative bacteria was studied; the results for two Gram-positive organisms (Saccharomyces cerevisiae and Streptococcus faecalis) and two Gram-negative bacteria (Escherichia coli and Proteus vulgaris) are illustrated in Figs. 1 and 2, respectively.

It was conceivable that the decreased leakage of ${ }^{32} \mathrm{P}$ compounds from Grampositive organisms might have been due simply to a smaller fraction of the cells having had their plasma membranes damaged by the treatment. That this explanation of the type of results given in Figs. 1 and 2 was unlikely was shown by the results of the following experiments. ${ }^{32} \mathrm{P}$-labelled Staphylococcus aureus was treated with ethanol solutions, the organisms deposited by centrifugation and the supernatant fluids removed. The organisms were then suspended in distilled water and the release of residual ${ }^{32} \mathrm{P}$ compounds determined after $10 \mathrm{~min}$. at room temperature. Escherichia coli was treated in the same manner. The results for $S$. aureus and $E$. coli are presented in Figs. 3 and 4, respectively; they show that the larger fraction of 32P material 'trapped' inside $S$. aureus treated with ethanol concentrations between 80-100\% readily leaked out when the organisms were subsequently suspended in water.

To test the possibility that the differences in the patterns of ${ }^{32} \mathrm{P}$ leakage in ethanol solutions were not due to a slower release from Gram-positive bacteria, the 
time course of leakage from Gram-positive and Gram-negative bacteria was studied. Organisms of Escherichia coli and Staphylococcus aureus were dispersed in $100 \%$ ethanol and filtered as described in the Methods, at intervals of time up to $20 \mathrm{~min}$. The time course for the release of ${ }^{32} \mathrm{P}$ compounds from $S$. aureus and $E$. coli are shown in Fig. 5. Although a smaller fraction of the total ${ }^{32} \mathrm{P}$ content leaked out from $S$. aureus in $100 \%$ ethanol, the fraction was released at about the same speed as that observed for $E$. coli.

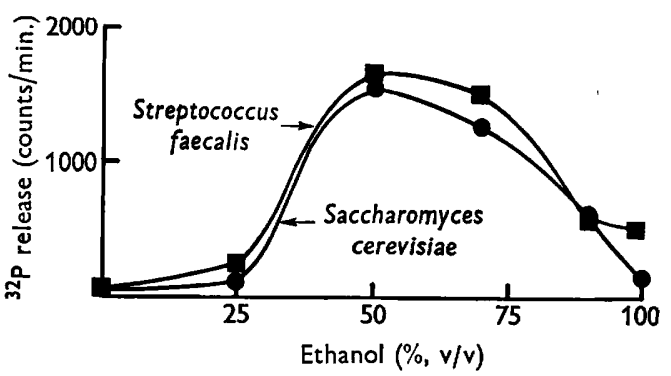

Fig. 1

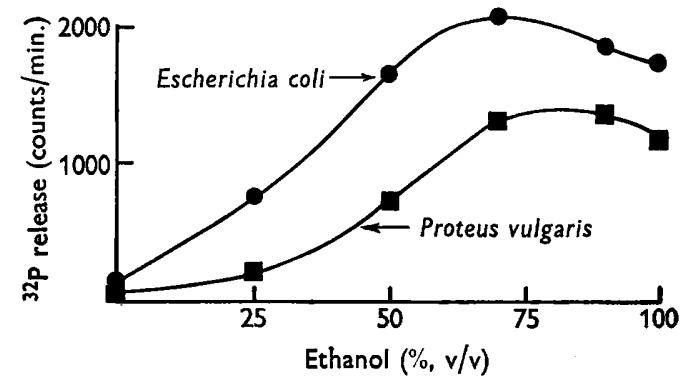

Fig. 2

Fig. 1. Leakage of ${ }^{32} \mathrm{P}$ compounds from Streptococcus faecalis and Saccharomyces cerevisiae. Organisms suspended in ethanol solutions for $10 \mathrm{~min}$. at room temperature.

Fig. 2. Leakage of ${ }^{32} \mathrm{P}$ compounds from Escherichia coli and Proteus vulgaris. Organisms suspended in ethanol solutions for $10 \mathrm{~min}$. at room temperature.

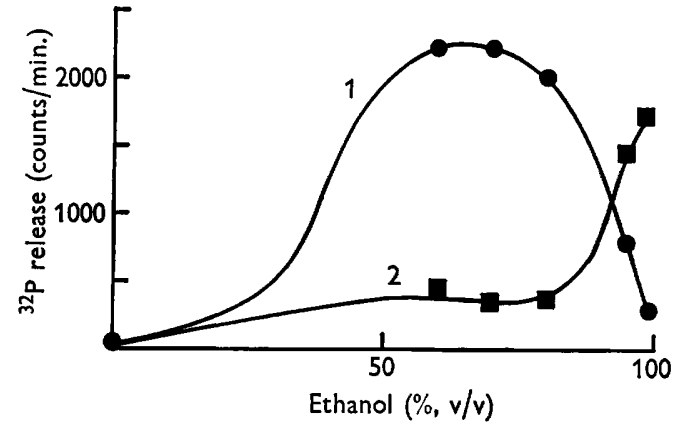

Fig. 3

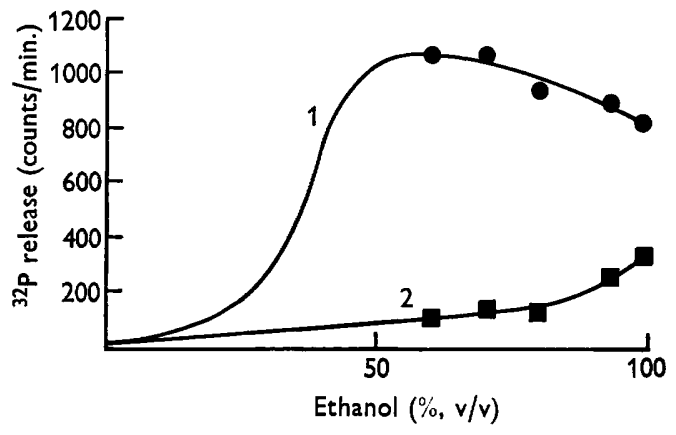

Fig. 4

Fig. 3. Leakage of ${ }^{32} \mathrm{P}$ compounds from Staphylococcus aureus suspended in ethanol solutions for $10 \mathrm{~min}$. at room temperature (curve 1) and the subsequent release of ${ }^{32 P}$ compounds into distilled water when deposits of cocci from curve 1 samples were suspended in distilled water for $10 \mathrm{~min}$. at room temperature (curve 2).

Fig. 4. Leakage of ${ }^{32} \mathrm{P}$ compounds from Escherichia coli suspended in ethanol solutions for $10 \mathrm{~min}$. at room temperature (curve 1 ) and the subsequent release of ${ }^{32} \mathrm{P}$ compounds into distilled water when deposits of organisms from curve 1 samples were suspended in distilled water for $10 \mathrm{~min}$. at room temperature (curve 2).

Experiments were performed with a collection of Gram-positive and Gramnegative organisms to determine the release of ${ }^{32} \mathrm{P}$ compounds in $100 \%$ ethanol. The leakage in $100 \%$ ethanol was determined in relation to the maximum leakage occurring at lower ethanol concentrations (usually at 50-75\%, v/v, ethanol in 
water) and has been expressed as a percentage of the maximum release in the results summarized in Table 3.

These differences between the Gram-positive and Gram-negative organisms only establish that the passage of certain small molecules (inorganic phosphate, nucleotides, etc.; Salton, 1951) across the wall or wall-membrane of Gram-positive bacteria is impeded when they are suspended in high concentrations of ethanol, whereas many of the Gram-negative bacteria were affected to a lesser degree. This finding in itself gives not more than a clue about a likely mechanism of the Gram reaction and suggests that the crystal violet + iodine complex is 'trapped' inside the organisms when the 'permeability' of the outer wall is decreased on treatment with concentrations of ethanol exceeding $90 \%$.

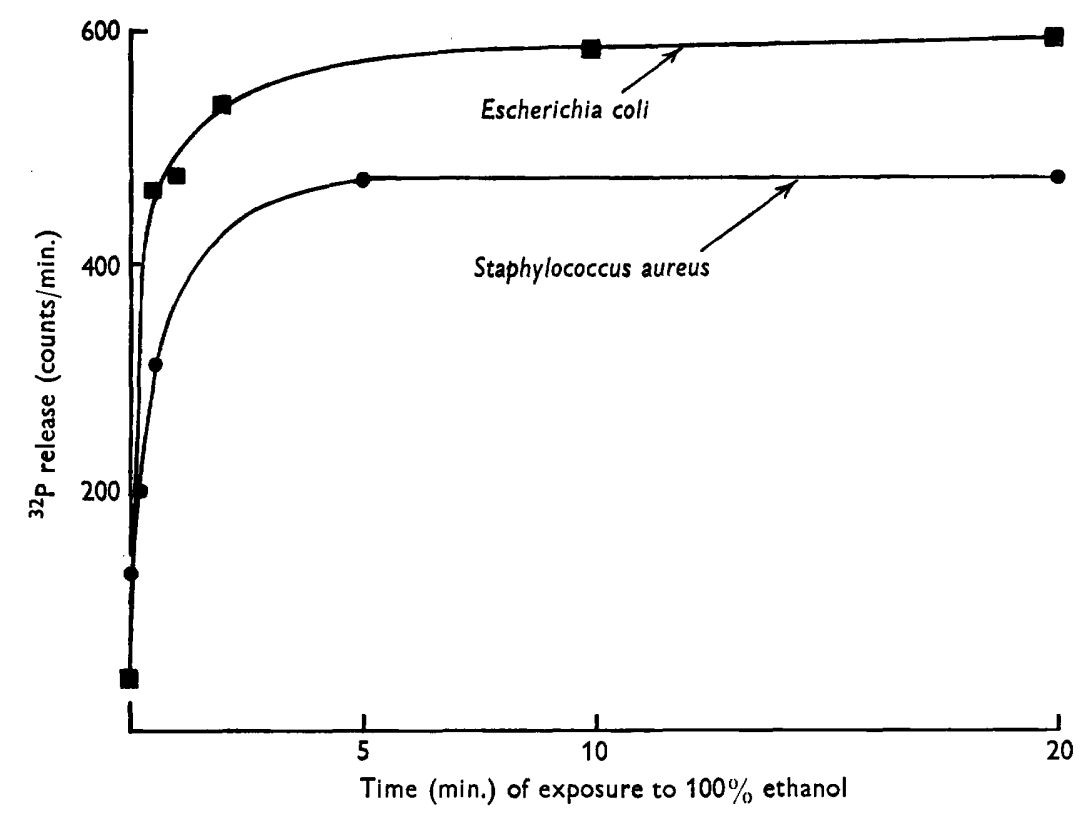

Fig. 5. The time course for the release of ${ }^{29}$ compounds from Escherichia coli and Staphylococcus aureus suspended in $100 \%$ ethanol at room temperature.

Unfortunately the role of mordanting with iodine in the Gram reaction could not be investigated in relation to the leakage of ${ }^{32} \mathbf{P}$ at different ethanol concentrations, as pretreatment of the bacteria with the iodine solution resulted in an immediate loss of intracellular ${ }^{32} \mathrm{P}$ compounds from Gram-positive and from Gram-negative bacteria. It seems likely that a more successful approach to the problem of the role of mordanting with iodine might be to study the penetration of small molecules into organisms suspended in ethanol before and after treatment with iodine solutions.

\section{Effects of mechanical rupture and wall removal on extractability of crystal violet +iodine complex from suspensions of Gram-stained organisms}

If, as the above results and the iodine permeability effects reported by Kaplan \& Kaplan (1938) and Bartholomew et al. (1959) suggest, the pore size of the wall of Gram-positive bacteria is decreased by mordanting with iodine and dehydration 
with $95 \%$ ethanol, thereby trapping the crystal violet+iodine (CVI) complex within its boundary, then mechanical rupture or enzymic removal of the wall after Gram staining should then render the CVI complex accessible to extraction.

Table 3. The relationship between the Gram reaction and the leakage of ${ }^{32} \mathrm{P}$ compounds from labelled bacteria exposed to about $100 \%$ ethanol

\begin{tabular}{|c|c|c|}
\hline $\begin{array}{l}\text { Gram } \\
\text { reaction }\end{array}$ & Organism & $\begin{array}{l}{ }^{82} \mathrm{P} \text { rele } \\
(\%) \text { rela } \\
\text { to maxin }\end{array}$ \\
\hline- & Pseudomonas sp. & \\
\hline- & Proteus vulgaris & $\mathbf{9 0}$ \\
\hline- & Escherichia coli & 84 \\
\hline - & Alcaligenes faecalis & 78 \\
\hline- & Vibrio metchnikovii & \\
\hline- & Salmonella gallinarum & $\gamma$ \\
\hline- & Aerobacter aerogenes & 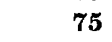 \\
\hline- & Chromobacterium prodigiosum & 6 \\
\hline- & Neisseria catarrhalis & 65 \\
\hline- & Pseudomonas fluorescens & 60 \\
\hline- & Spirillum serpens & 56 \\
\hline- & Escherichia dispar & $\mathbf{5}$ \\
\hline- & Bacillus brevis & 54 \\
\hline+ & Leuconostoc mesenteroides & 43 \\
\hline+ & Clostridium perfringens & 36 \\
\hline+ & Micrococcus lysodeikticus & $\mathbf{3 5}$ \\
\hline+ & Candida pulcherrima & 34 \\
\hline+ & Streptococcus faecalis & 33 \\
\hline+ & Clostridium sporogenes & $\mathbf{3 0}$ \\
\hline+ & Lactobacillus arabinosus & 30 \\
\hline+ & Staphylococcus aureus & 26 \\
\hline+ & Bacillus megaterium & 22 \\
\hline+ & Corynebacterium hoffmanni & 17 \\
\hline+ & C. xerosis & 13 \\
\hline+ & Bacillus cereus & 11 \\
\hline+ & Saccharomyces cereoisiae & 10 \\
\hline
\end{tabular}

* Maximum ${ }^{32}$ P released from organism usually occurred in $50-75 \%(v / v)$ ethanol in water solution.

Heated washed suspensions of Bacillus megaterium, Micrococcus lysodeikticus and Saccharomyces cerevisiae were Gram stained as described by Wensinck \& Boevé (1957). The Gram-positive organisms were washed several times with $96 \%$ ethanol (no counter stain used), the supernatant solutions decanted off and the packed organisms drained before dispersing in distilled water. These suspensions were mixed with Ballotini beads and shaken in the Mickle apparatus under the conditions normally used for cell-wall isolation (Salton \& Horne, 1951). The beads were separated by allowing them to settle and after several washes with distilled water the fluid containing the disintegrated organisms was centrifuged. The deposits from disintegrated organisms and untreated Gram-positive organisms were suspended in $96 \%$ ethanol and centrifuged again. On extraction with $96 \%$ ethanol the control organisms not submitted to mechanical disintegration still remained strongly Gram-positive whereas the material from the ruptured organisms was decolorized.

Salton (1953b) showed that the walls of heated Bacillus megaterium and Micrococcus lysodeikticus were removed on incubation with egg-white lysozyme, leaving 
the coagulated protoplasmic bodies. Similar experiments were performed with suspensions of organisms Gram stained by the method of Wensinck \& Boevé (1957). After decolorizing by washing several times with $96 \%$ ethanol on the centrifuge, the packed organisms were drained and suspended in 0.067 M-phosphate buffer ( $\mathrm{pH} 7$ ) and incubated with $50 \mu \mathrm{g}$. lysozyme $/ \mathrm{ml}$. for $1 \mathrm{hr}$. at $37^{\circ}$. Control preparations without lysozyme were incubated under the same conditions. Lysozyme-treated and untreated organisms were then deposited by centrifugation, the supernatant fluids decanted, the deposits washed with distilled water and the washing fluid drained off. The deposits were then dispersed in $96 \%$ ethanol and the organisms sedimented by centrifugation. Under these conditions only residual amounts of crystal violet remained in the deposits from the lysozyme-treated preparations; the organisms not exposed to lysozyme action were still strongly Gram-positive.

\section{DISCUSSION}

Burke \& Barnes (1929) suggested that the Gram reaction could be explained by the impermeability of the walls of Gram-positive bacteria to the crystal violet+ iodine complex. Both before and since the proposal of this mechanism, attempts have been made to relate the Gram reaction to specific chemical compounds in Gram-positive bacteria. Convincing correlations between the presence of certain cellular constituents and a positive Gram reaction have ultimately broken down and as pointed out by Shugar \& Baranowska (1957) the demonstration of certain substances in Gram-positive organisms 'does not necessarily mean that this component is responsible for Gram staining, but only that it may be one of the manifestations of the differences in physiological and physico-chemical characteristics between Gram-positive and Gram-negative organisms'. Indeed, a wide variety of simple and polymeric substances can behave as Gram-positive material (Shugar \& Baranowska, 1957).

Strong support for the 'permeability' mechanism of the Gram reaction came from the earlier studies of Kaplan \& Kaplan (1933) and more recently from the work of Bartholomew et al. (1959). A clearer interpretation of the mechanism of the Gram reaction has only been possible as a result of the studies of Wensinck \& Boevé (1957) who were the first to provide convincing quantitative information about the sequence of steps in the Gram reaction and the points of departure in behaviour between the Gram-positive and Gram-negative organisms on decolorization with ethanol. The similarity between their patterns of extractability of crystal violet + iodine (CVI) complex and the release of ${ }^{32} \mathrm{P}$ compounds at different ethanol concentrations shown in the present investigations (Figs. 1, 2), is striking. Thus, the ethanol concentration used as the differentiating step in the Gram stain decreases the accessibility of the CVI complex and the same concentrations have been shown to impede the passage of intracellular ${ }^{32} \mathrm{P}$ compounds across the walls of Gram-positive organisms. These results together with the observations on disrupted Gram-stained organisms involving either simple mechanical damage or enzymic removal of wall, strongly support the view that a Gram-positive reaction is due to the CVI complex being 'trapped' within the organisms owing to dehydration and diminution in pore size of the walls of Gram-positive organisms. It also appears likely that mordanting with iodine could have a twofold effect of forming a CVI complex as well as an 
association between iodine atoms and $\mathrm{OH}$ groups of polysaccharide (composed of sugars and/or amino sugars) components of the walls. This might further decrease the pore size on dehydration of the structure in ethanol, in a similar manner to the decrease in the internal diameter of the starch helix which accompanies the association of the large iodine atom with this polysaccharide (Greenwood, 1956).

If the Gram reaction is thus due to the physico-chemical state of the wall during differentiation with $96 \%$ ethanol, then many of the conflicting results of earlier investigation can be readily understood. Any breach in the mechanical integrity of the wall either before or after Gram staining would render the CVI complex more accessible to extraction. Gerhardt et al. (1956) indeed attempted such a conclusive experiment with Bacillus megaterium but their results were not entirely satisfactory and not as clear cut as the data obtained from washed Gram-stained suspensions. The loss of Gram positivity on disintegration, autolysis and digestion of heated organisms with lysozyme (Webb, 1948) and even the effects of ageing, are all readily understandable if an intact rigid wall is needed as a barrier for the retention of the CVI complex. The presence of cell-wall degrading enzymes in bacteria has been well established (Mitchell \& Moyle, 1957; Salton, 1956) and could account for the conversion of bacteria to the Gram-negative state.

It is now generally agreed that the Gram reaction is not an 'all or none' phenomenon, for gradations between Gram-positive and Gram-negative extremes have long been recognized (Neide, 1904; Churchman \& Siegel, 1928; Shugar \& Baranowska, 1958). Some of these quantitative differences may well be accounted for by the presence of more mucopeptide component in the walls of organisms within the Gram-negative group. The amino sugar content of the walls is probably a good index of the amount of cell-wall mucopeptide and it is of interest to note that several of the organisms intermediate between the extremes of ${ }^{32} \mathrm{P}$ leakage in ethanol (Table 3) also contain appreciable quantities of amino sugar in the walls (Table 2). Thus the total amount of mucopeptide and polysaccharide complex in the walls of bacteria and yeasts may have an important bearing on the quantitative aspects of the Gram reaction. The physicochemical state of the wall mucopeptides and polysaccharides may also be of considerable importance in determining the response in the Gram reaction. It appears likely that the mucopeptide polymers in the walls of Grampositive bacteria form thick continuous sheets, whereas in a Gram-negative organism such as Escherichia coli the mucopeptide component responsible for the rigidity of the wall is present as a very thin layer (Weidel, Frank \& Martin, 1960). Gramvariable properties may thus be explicable on the basis of mucopeptide layers of thickness intermediate between those found for the two extremes of Gram-positive and Gram-negative bacteria. More information about the physico-chemical structure of microbial cell walls is obviously needed before a clearer picture will emerge of the effects of the differentiation with ethanol which leads to a Gram-positive or Gram-negative reaction; and the role of iodine and the possible groups in the wall with which it may associate must be further investigated.

I wish to thank Mr J. G. Pavlik for preparing cell walls and carrying out some analyses. 


\section{REFERENCES}

Armstrong, J. J., Baddiley, J., Buchanan, J. G., Carss, B. \& Greenberg, G. R. (1958). Isolation and structure of ribitol phosphate derivatives (teichoic acids) from bacterial cell walls. J. chem. Soc. p. 4344 .

Bartholomew, J. W., Cromweli, T. \& Finkelstein, H. (1959). Correlation between iodine permeability and the Gram characteristic of cells. Nature, Lond. 183, 123.

Bartholomew, J. W. \& MrtTwer, T. (1952). The Gram stain. Bact. Rev. 16, 1.

Benians, T. H. C. (1920). A further investigation into the principles underlying Gram's stain, with special reference to the bacterial cell membrane. J. Path. Bact. $23,401$.

Burke, V. \& Barnes, M. W. (1929). The cell wall and the gram reaction. J. Bact. 18, 69.

Chelton, E. T. J. \& Jones, A. S. (1959). The Gram-staining reaction of disintegrated microorganisms. J. gen. Microbiol. 21, 652.

Churchman, J. W. \& Sieger, L. (1928). Cultural separation of bacteria on the basis of triphenylmethane coefficients. Stain Tech. 3, 73.

Deussen, E. (1921). Die Gramsche Bakterienfärbung, ihr Wesen und ihre Bedeutung. Z. Hyg. Infektr.-Kr. 93, 512.

Dubos, R. J. \& Macheod, C. M. (1938). The effect of a tissue enzyme upon pneumococei. J. exp. Med. 67, 791.

Eisenberg, P. (1910). Zur Theorie der Gramfestigkeit. Zbl. Bakt. (Abt. 1, Orig.), 56, 193.

Falcone, G. \& Nickerson, W. J. (1956). Cell-wall mannan-protein of Baker's yeast. Science, 124, 272.

Fischer, R. \& LaRose, P. (1952). Contribution on the behaviour and structure of the cytoplasmic membrane of bacteria. Canad. J. med. Sci. 30, 86.

Gerhardt, P., Vennes, J. W. \& BritT, E. M. (1956). Gram reaction of isolated protoplasts and surface membranes of Bacillus megaterium. J. Bact. 72, 721.

Gram, C. (1884). Uber die isolirte Färbung der Schizomyceten in Schnitt-und Trockenpräparaten. Fortschr. Med. 2, 185.

Greenwood, C. T. (1956). Aspects of the physical chemistry of starch. Advanc. Carbohyd. Chem. 11, 335.

Henry, H. \& Stacey, M. (1946). Histochemistry of the Gram staining reaction for microorganisms. Proc. Roy. Soc. B, 133, 391.

Henry, H., Stacey, M. \& Teece, E. G. (1945). Nature of the gram positive complex in microorganisms. Nature, Lond. 156, 720.

Herbst, E. J., Weaver, R. H. \& Keister, D. L. (1958). The Gram reaction and cell composition: diamines and polyamines. Arch. Biochem. Biophys. 75, 171.

HUCKER, G. J. (1921). A new modification and application of the Gram stain. J. Bact. 6, 395.

Jones, A. S., Rizvi, S. B. H. \& Stacey, M. (1958). The phosphorus-containing compounds of Gram-positive and Gram-negative organisms in relation to the Gram staining reaction. J. gen. Microbiol. 18, 597.

KAPLAN, M. L. \& KAPLAN, L. (1933). The Gram stain and differential staining. J. Bact. 25, 309.

Kessler, G. \& Nickerson, W. J. (1959). Glucomannan-protein complexes from cell walls of yeasts. J. biol. Chem. 234, 2281.

Lamanna, C. \& Mallette, M. F. (1950). The relation of the Gram stain to the cell wall and the ribonucleic acid content of the cell. J. Bact. 60, 499 .

Mitcheld, P. \& Moyle, J. (1950). Occurrence of a phosphoric ester in certain bacteria: its relation to Gram staining and penicillin sensitivity. Nature, Lond. 166, 218.

Mrtcheld, P. \& MoYLe, J. (1951). The glycerophospho-protein complex envelope of Micrococcus pyogenes. J. gen. Microbiol. 5, 981.

Mrtchell, P. \& Moyle, J. (1954). The Gram reaction and cell composition: nucleic acids and other phosphate fractions. J. gen. Microbiol. 10, 533 .

Mrtcheld, P. \& MoYle, J. (1957). Autolytic release and osmotic properties of 'protoplasts' from Staphylococcus aureus. J. gen. Microbiol. 16, 184. 
Mrtcheld, P. \& Moyle, J. (1958). The positic acids of Staphylococcus aureus and other Gram-positive penicillin-sensitive bacteria: hydrolytic products and possible backbone structure. Proc. R. phys. Soc. Edinb. 27, 79.

NeIDE, E. (1904). Die Alkoholentfärbung der nach Gram gefärben Bakterien als speciesdiagnose, in Verbindung mit einer Untersuchung der für die Gramfarbung in Betracht kommenden Faktoren. Zbl. Bakt. (Abt. 1, Orig.), 35, 508.

Northcote, D. H. \& HorNe, R. W. (1952). The chemical composition and structure of the yeast cell wall. Biochem. J. 51, 232.

Roberts, R. B., Abelson, P. H., Cowie, D. B., Bolton, E. T. \& Britten, R. J. (1955). Studies of biosynthesis in Escherichia coli. Publ. Carneg. Instn, No. 607.

Rondle, C. J. M. \& Morgan, W. T. J. (1955). The determination of glucosamine and galactosamine. Biochem. J. 61, 586.

SALTON, M. R. J. (1951). The adsorption of cetyltrimethylammonium bromide by bacteria, its action in releasing cellular constituents and its bactericidal effects. J. gen. Microbiol. $5,391$.

Salton, M. R. J. (1953a). The composition of the cell walls of some Gram-positive and Gram-negative bacteria. Biochim, biophys. Acta, 10, 512 .

Salton, M. R. J. (1953b). Cell structure and enzymic lysis of bacteria. J. gen. Microbiol. $9,512$.

Salton, M. R. J. (1956). Bacterial cell walls. In Bacterial Anatomy. Symp. Soc. gen. Microbiol. 6, 81.

Salton, M. R. J. (1958). The lysis of micro-organisms by lysozyme and related enzymes. J. gen. Microbiol. 18, 481.

Salton, M. R. J. (1961 $a)$. The anatomy of the bacterial surface. Bact. Rev. 25, 77.

Salton, M. R. J. (1961b). Microbial Cell Walls. New York: John Wiley \& Sons.

Salton, M. R. J. \& HoRne, R. W. (1951). Methods of preparation and some properties of cell walls. Biochim. biophys. Acta, $7,177$.

Salton, M. R. J. \& Pavlik, J. G. (1960). Wall composition and sensitivity to lysozyme. Biochim. biophys. Acta, 39, 398.

Salton, M. R. J. \& Shafa, F. (1958). Some changes in the surface structure of Gramnegative bacteria induced by penicillin action. Nature, Lond. 181, 1321.

Schumachen, J. (1928). Utber die chemische zusammensetzung der lipoidsaüre und über künstlich grampositiv gemachte Hefezellen. Zbl. Bakt. (Abt. 1, Orig.), 109, 181.

Shugar, D. \& Baranowska, J. (1957). Gram staining of extracellular material. Biochim. biophys. Acta, 23, 227.

Shugar, D. \& Baranowska, J. (1958). Quantitative Gram-staining with labelled iodine. Nature, Lond. 181, 357.

Stacey, M. (1949). The nature of the surface of Gram-positive bacteria. In The Bacterial Surface. Symp. Soc. gen. Microbiol. $1,29$.

Stearn, E. W. \& Stearn, A. E. (1924). A new theory of the gram reaction. J. Bact. 9, 479.

Stearn, E. W. \& Stearn, A. E. (1930). The nature of the gram compound and its bearing on the mechanism of staining. J. Bact. 20, 287.

WEBB, M. (1948). The action of lysozyme on heat-killed gram-positive microorganisms. J. gen. Microbiol. 2, 260.

Weidel, W., Frank, H. \& Martin, H. H. (1960). The rigid layer of the cell wall of Escherichia coli strain B. J. gen. Microbiol. 22, 158.

Wensinck, F. \& Bonvé, J. J. (1957). Quantitative analysis of the Gram reaction. J. gen. Microbiol. 17, 401. 